\title{
Current Research Projects on Educational Problems of Third World Countries: a survey among German educationists
}

\author{
Volker Lenhart
}

\section{The Survey and the Sample}

In January 1984 a questionnaire on current research projects was sent to 80 educationists who were either members of the 'Committee of Educational Research in Cooperation with Third World Countries' or were affiliated to it. The questionnaire reached the majority of educational Third World researchers in German universities - thus is not necessarily true for those in separate research institutions. Nevertheless the sample can be considered relatively representative for the target group of educationists interested in educational problems of Third World countries and their interrelationship with educational in Europe.

Only 15 sent back a filled-in questionnaire. Though it may be doubted whether all the ongoing projects of researchers in the sample were reported, there is some indication that not too many were missed. The 15 projects evidently give a good impression of ongoing research activities.

\section{The Information}

There were 22 researchers engaged in the 15 projects. Three educationists report activities in two projects. Most activities are 'one man (woman)' endeavours. The researchers are either faculty members of universities (13), or staff members of institutions of technical cooperation (1), or independent institutes of educational planning in Germany (8).

To give an impression of the research topics, the key words and descriptions of the projects are listed:

- projected and real chances - educational factors within the sociology of migrants from the rural areas to the town of Kisangani, Zaire

- the education system and economic development

- the forgotten resource - harmony and conflict in traditional education and modern schooling in Africa

- cultural heritage in modern mass communication (Singapore)
- educational history of West Africa - stages of economic and educational peripheralisation

- the relationship between society and education in South East Asia

- society and education in the People's Republic of China as mirrored in recent Chinese textbooks

- the relationship between secondary and higher education in the People's Republic of China

- the importance of formal certificates and nonformal training for the labour market in North East Brazil

- constituent traits of childhood in Africa

- strengthening educational research and planning in Paraguay

- vocational training for refugees and Sudanese

- Southern Africa - a crisis region as a learning case (in German schools)

- sexual education for Turkish and German youths - a project of intercultural education

- vocational training for immigrants from the Near East (especially Turkey).

Seven projects concentrate on problems of formal education, six focus on the interdependence of formal, non-formal and/or informal education, one activity concerns non-formal education, and one general socialisation or informal education. Twelve studies focus on educational problems in Third World countries, one concentrates on how to treat a Third World crisis in German schools, two deal with Third World problems within the societal context of an industrialised country (Germany). These last two studies are surely not representative of research on the children of migrant workers in Germany, but the projects are examples of the minority of Gastarbeiter - research activities that are conceptualised in terms of societal and cultural contact and conflict between western Europe and quasi-Third World countries at the South East edges of Europe.

W.S Bullerin. 1984. vol 15 no 4. Institute of Development $\mathbf{S}$ tudies, Sussex 
Researchers of the sample do not conceptualise the developmental relevance of their results in terms of current Third World oriented macrosociological paradigms. They prefer formulations of a more concrete level, problem descriptions and theoretical approaches nearer to their immediate research items. Exceptions to this more concrete, pragmatic approach are two formulations: 'Industrialisation, modernisation and change in vocational training' and 'Contradictions between the official educational policy based on modernisation theory and the real process of recruiting and employing industrial workers'.

The geographic or political interests range from 'Aix-La-Chapelle, Germany', via 'Sous-Région de la Tshopo and the city of Kisangani, Zaire', to 'Paraguay', 'Sudan', 'southern Africa', 'west Africa', and ' 92 Third World countries (without Arabic OPEC states)'. Most projects focus on present problems, two take a historical perspective 'from 1500 till independence', and 'from later colonial period to present'.

Only five of the 15 projects report firmly established contacts with research partners in the Third World. The partners are mainly members of university faculties and research institutions, few are in government agencies. Nine studies are based on own (quantitative) empirical data collection, two are secondary analyses of aggregated data, the others rely on a more qualitative approach based on documents and published research. Only four projects declare a need for resource materials (for example, historical documents) and offer exchange and cooperation.

Eleven studies are 'personal projects', two are projects commissioned by institutions of technical cooperation, one is a 'cooperative project' (that is, it is planned and carried out by a group of researchers in Zaire and Germany on their own initiative), one is a post-doctoral thesis (Habilitationschrift).

Two studies are in the planning stage, five in the phase of collecting data and material, two in the phase of data processing and interpretation. For six there is a final report in progress or completed. Five projects have to rely mainly or exclusively on their own private money, two are supported by the university or the employing research institute, five are financed by major research funding institutions, two declare the question of financing 'still open'. Just one project is financed by a government of a Third World country. A combination of financial resources is reported for four studies.

The results are to be published in the form of a monograph in nine cases, an article in a research journal is planned for six studies, a contribution to an omnibus volume is intended for two studies, while one EJC-project reports intended publication via EJCmicrofiche (multiple item marking was possible, so the answers do not sum to 15 ). 